\title{
Evaluating adaptation and the production development of Finnish agriculture in climate and global change
}

\author{
Heikki Lehtonen \\ Natural Resources Institute Finland (Luke), Economy and Society, \\ Latokartanonkaari 9, FI-00790 Helsinki, Finland \\ e-mail: heikki.lehtonen@luke.fi
}

\begin{abstract}
Agricultural product prices and policies influence the development of crop yields under climate change through farm level management decisions. On this basis, five main scenarios were specified for agricultural commodity prices and crop yields. An economic agricultural sector model was used in order to assess the impacts of the scenarios on production, land use and farm income in Finland. The results suggest that falling crop yields, if realized due to low prices and restrictive policies, will result in decreasing crop and livestock production and increasing nutrient surplus. Slowly increasing crop yields could stabilise production and increase farm income. Significantly higher crop prices and yields are required, however, for any marked increase in production in Finland. Cereals production would increase relatively more than livestock production, if there were high prices for agricultural products. This is explained by abundant land resources, a high opportunity cost of labour and policies maintaining current dairy and beef production.
\end{abstract}

Key words: agricultural sector modelling, economic adjustment, global prices, climate change, Finnish agriculture

\section{Introduction}

There are two main global drivers affecting agriculture in northern latitudes. One is climate change, i.e. global warming, leading to a gradually increasing length and temperature sum (accumulated degree days when average daily temperature during the growing period exceeds 5 degrees Celsius) of the growing period in northern Europe (Ruosteenoja et al. 2010), and another is the gradually increasing global demand for food, driven by an increasing global population and higher income levels, implying a possible increase in the real prices of food (FAO 2012, Godfray et al. 2011, Tilman et al. 2011). Increasing incomes worldwide implies a more inelastic food demand which contributes to higher price volatility on food markets (Martin et al. 2008). Climate change is expected to increase potential yields in northern Europe (Peltonen-Sainio et al. 2009, Olesen et al. 2011). The realisation of higher yields at the farm level is uncertain, however. Predicted increases in precipitation in the sowing or harvest periods and increased variability of temperatures and precipitation throughout the growing season may considerably inhibit possible yield gains, especially if plant breeding and management practices do not adjust adequately in response to the challenges posed by increasing weather variability (Rötter et al. 2011). Olesen et al. (2011) conclude that a wide range of adaptation options exists in most European regions to mitigate many of the negative impacts of climate change on crop production, but these impacts are still mostly negative over large areas across Europe, considering all the effects of climate change and possibilities for adaptation. If the net effects of climate change were to be at all positive in northern Europe, climate change might then improve the competitive position of northern agriculture. In some earlier studies, a significant increase in productivity and agricultural production has been anticipated in northern Europe, based on changes in bio-physical production conditions and an abundant land area, potentially available for intensified agricultural production (e.g. Berry et al. 2006).

However, the high production costs of northern European agriculture may effectively inhibit any increase in agricultural production. Other agricultural production regions with low (marginal) costs of production are likely to respond more effectively to the increasing demand for food, if not restricted by, for instance, the limited availability of agricultural land and other infrastructures, the low overall productivity in agriculture, a lack of capital, or deficiencies in public or private administration. Nevertheless, the profitability of investments in agriculture, including those promoting crop yields, is crucially dependent on global price developments. Agricultural support payments, in the EU largely decoupled from production, cannot provide primary incentives for agricultural investments. It is important from the farmers' point of view to evaluate whether it pays off to aim for high yields by using variable inputs, and even investing in, for example, soil improvements which only pay off in the longer run. Relevant questions for farmers and the whole agricultural sector are: What do the increasing yields contribute in agriculture? What kind of changes in production, land use, nutrient balance and farm income can be expected? 
The objective of this study is to answer these questions by evaluating the likely production and income development of Finnish agriculture in different plausible future realizations of global agricultural commodity prices, and in the different realizations of future crop yield levels, dependent on future commodity prices. Since market prices for agricultural commodities, as well as agricultural policies, largely influence farmers' efforts in adapting to climate and market changes, we specify plausible price-yield scenarios, with specific descriptions of farm management driving agricultural adaptations and crop yields. The impacts of these future scenarios on agricultural production, land use, use of nutrients and farm income are evaluated using an economic agricultural sector model, simulating the economic rational decision-making in the agricultural sector up to 2050. The main results and findings are presented and discussed, and conclusions are drawn of the possibilities of Finnish agriculture adapting to future climate and market changes, primarily from the viewpoint of agricultural economics. Conclusions are also drawn about what kind of market and policy developments are needed in order to increase or maintain existing agricultural production in Finland.

This paper proceeds as follows. First, recent literature on future crop productivity subject to climate change is briefly reviewed from the point of view of northern Europe and Finland. Price-yield scenarios are specified based on crop productivity estimates, on studies of global food markets and trade, and on recent studies of farm level management choices and adaptation. These scenarios include descriptions of the farm level management required to achieve the specific yield levels. The sector model (DREMFIA) is introduced and used in evaluating the impacts of the price-yield -scenarios on production, land and nutrient use and farm income. The results are presented and discussed before the main conclusions are given.

\section{Materials and methods}

\section{Climate change and its impacts on crop productivity in Finland}

Projected climate change in Finland up to 2100, with a reference period of 1971-2000, has been reported as follows (Jylhä et al 2009, Ruosteenoja et al. 2010). Annual temperature increases by $2-6{ }^{\circ} \mathrm{C}$ on average, in winter 3 $-9{ }^{\circ} \mathrm{C}$, and in summer by $1-5{ }^{\circ} \mathrm{C}$. Annual precipitation increases by $12-22 \%$ (in winter $10-40 \%$, in summer by 0 $-20 \%)$. Growing season length increases by 30-45 days until 2100 . The temperature sum during the growing period is predicted to increase as follows: Middle Finland, from 1100 to 1600 degree days; Southern Finland, from 1300 to 1900; Northern Finland, from 900 to 1200 degree days. The increasing frequency of rainy days, heavy rainfalls and dry spells may inhibit the increase in crop yield potential due to the higher temperature sum (Lehtonen et al. 2014b, Peltonen-Sainio et al. 2009). The decreased length of the thermal winter, reduced snow cover and permafrost in northern Europe (recently reported by IPCC 2014) are likely to negatively affect the overwintering of grasslands and winter cereals for some decades to come (Peltonen-Sainio et al. 2009). Impacts of climate change on crop yields and the profitability of agriculture are highly uncertain. While non-negligible positive impacts of climate change may be anticipated for northern Europe (ibid), increasing climatic variability with a higher frequency of extreme events, pest pressure and continuous changes in the markets may present very significant challenges to agriculture in the Nordic countries (Hakala et al. 2011).

Rötter et. al. (2012) give an overall summary of the impacts of climate change on the agro-meteorological indicators that are most relevant in crop yields. They conclude that a longer growing season and higher effective temperature sum are likely to increase crop yield potential, while an increasing number of dry days and more frequent adverse weather events are factors that may significantly affect crop yield levels and their inter-annual changes.

Peltonen-Sainio et al. (2009) conclude that the realisation of the increased yield potential requires adaptation to: 1) elevated daily mean temperatures that interfere with the development rate of seed crops under long days, 2) relative reductions in water availability at critical phases of yield determination, 3) greater pest and disease pressure, 4) other uncertainties caused by weather extremes, and 5) a generally greater need for inputs such as fertilizers for non-nitrogen fixing crops.

Shifting from current cultivars to slowly maturing new cultivars may reduce vulnerability to (early summer) drought and increase tolerance to heat stress. Earlier sowing times may imply better utilization of winter and spring time precipitation, provided there is sufficient water retention capacity in the soil. However, improved or altered crop protection is also needed, due to increasing plant disease and pest pressure. 
Currently, the use of fungicides is relatively less common than the use of herbicides in Finnish crop production. 198 tons of the active substances of fungicides and 1224 tons of active substances of herbicides were sold in Finland in 2012) (Tukes, 2013a). The use of fungicides and other crop protection chemicals, associated with the integrated crop protection scheme (where chemicals are only used in addition to other measures, if needed) can be increased. However, more diverse crop rotations may relieve disease pressure, and they are likely to be needed in order to improve soil structure affecting water retention capacity and nutrient availability for plants (Hakala et al. 2011). Higher crop yield potential also implies increased or altered fertilisation levels, possibly through changed timing and split fertilization to more than one occasion per growing period. Improved soil structure, soil pH and drainage are likely to be needed to improve crop yields and also to avoid an increasing risk of nutrient leaching into watercourses due to more frequent extreme weather events.

Höglind et al. (2013) simulated grass yields in various locations of northern Europe under A1B climate scenario, representing a 'median' climate scenario of a significant ( +3 degrees Celsius increase in average global temperature until 2100, from 1980 to1999 average), but not very strong warming of climate (IPCC 2014). The main result, in the case of Jokioinen, located in southern Finland, was that average dry matter yields of grass increases while the annual volatility of grass yield increases slightly as well. The increase in yield was mainly because of the increased number of cuts per year rather than increased yield from individual cuts. The yield response to climate change, up to the mid- $21^{\text {st }}$ century, was $11 \%$ for grass production per ha in southern Finland and more than $20 \%$ in central areas of Finland (the Kuopio region) with the assumption of optimal overwintering conditions and current $\mathrm{CO}_{2}$ level. However, possible problems in overwintering may reduce the yield potential. They can be avoided through partial re-sowing of grassland, which implies higher costs. Higher mean yields may nevertheless result in cost savings on feed and manure logistics.

Rötter et al. (2013) estimated the yields of cereal crops in Finland for the 21st century under SRES A2 climate scenario representing a 'high end' climate scenario with strongly increasing temperatures especially in the latter half of the $21^{\text {st }}$ century. SRES A2 is close to the RCP 8.5 scenario (see Rogelj et al. 2012 for the relationship between SRES and more recent RCP scenarios aimed at replacing SRES scenarios). However, SRES A2 is rather similar to SRES A1B (close to the RCP 6.0 scenario) in terms of temperature increase, up to 2050. The results of Rötter et al. (2013) suggest that the yield potential of major crops under climate change will most likely be sustained close to the current level, if new cultivars, better attuned to the longer growing season, are adopted. On sandy soils, or on other soils prone to drought, yields (especially those of the cultivars currently used) may decrease due to an increased frequency of drought. Cultivars more suited to a longer growing season may better tolerate drought periods.

Even if the climate change impacts on yields are dependent on location and soil type, the increase of grass yields due to climate change is more likely than the increase in the yield of cereals in Finland.

\section{Socio-economic drivers of crop yields}

Crop growth is one of the key drivers in the development of agricultural production, land use and nutrient balances. Nevertheless, in Finland there is already currently a large and widening gap between water-limited potential yields and actual observed average yields (Peltonen-Sainio et al. 2015). This so called "yield gap" is affected by socio-economic factors influencing the profitability of farm level management. The yield gap at a farm level in Finland can be narrowed by improving farm management such as a proper design of crop plans, applying crop rotation, providing an appropriate level of fertilization, carrying out fungicide and liming treatment (PeltonenSainio et al. 2015). These farm level measures mean increased or more accurate use of physical inputs (fertilizers, liming, crop protection, labour) or altered production organization, often implying more planning work, labour input or land area (e.g. crop rotation). All these imply costs, at least in the short run. These costs need to be covered by crop prices.

Low real prices of crops and discouraging and restrictive policies may lead to cost minimization rather than to improved management aimed at higher yields and narrowing the yield gap (Lehtonen et al. 2014a, 2015, Palosuo et. al. 2015). Lehtonen et al. (2014a) report that in a period of $10-20$ years in south-west Finland $20 \%$ higher crop prices from the 2009-2013 average levels may incentivise farm level changes in fertilization, liming, crop protection and crop rotation, leading to a $6-12 \%$ increase in the yields of spring cereals and oilseeds. The long time span of 20-30 years was used in the analysis in order to compare between stabilized yield levels (not short-term yield changes). On the other hand, cutting crop prices by 20\% from the 2009-2013 average level may lead to costminimising behaviour and a resultant decrease in the management actions mentioned above, and eventually in a $2-10 \%$ reduction in crop yields over a period of 10-20 years. 
Similar management and yield effects were calculated for central areas of Finland, the North Savo region, where yields of spring cereals may increase by up to $7-11 \%$ in the case of high prices, but decrease by as much as $12-15 \%$ in the case of low crop prices, compared to the 2009-2013 average prices (Lehtonen et al. 2015). These results were explained by empirically validated yield responses and related management decisions, integrated in a farm level dynamic optimization framework. Yield changes following management changes can be relatively greater in the longer term than, for instance, immediate yield responses to, for example, altered fertilisation.

In fact, future yields and prices are coupled, since yield-promoting management is not likely to be realized, at least not for very long, if not covered by (expected) market prices. Some farm-level measures could pay off even in the near future if market prices were high. Nevertheless, the experienced reality is not that bright. Yield gaps have increased (Peltonen-Sainio et al. 2015). Farmers trying to improve productivity early on have been impeded by rapidly increasing prices of agricultural inputs, and volatile agricultural commodity prices. Periods of low prices may significantly delay the pay-off time for the investments in improved crop yields. Hence, the profitability and viability of farming is greatly dependent on global markets, even if effective solutions are found to local problems.

Nelson et al. (2014) examined how nine global trade models of agriculture represent endogenous responses to seven standardized climate change scenarios produced by two climate and five crop models. The main climate change scenario used in the analysis represented a relatively strong global warming, i.e. a representative concentration pathway with end-of-century radiative forcing of $8.5 \mathrm{Wm}^{-2}$ (RCP 8.5; corresponding to SRES A2 scenario of strong warming). The reported responses from the global trade models include adjustments in yields, area, consumption, and international trade. Based on the consistent comparison of the outcomes, the aggregate agricultural output price index showed changes in real prices of between $-5 \%$ and $+30 \%$ until 2050 . Most models produced aggregated price changes of 0-20\%, however. Agricultural production, cropland area, trade, and prices showed a great degree of variability in response to climate change, while consumption, mainly driven by income levels, was relatively less affected by climate change. The sources of the differences included model structure and specification, and in particular, model assumptions about ease of land use conversion, intensification, and trade (ibid). In particular, land use conversions and shifts between extensive and intensive land use activities are not easily quantified due to large spatial variations in, for example, soil types. Thus, there is likely to be a significant uncertainty in the agricultural supply response in the long-term.

According to the various model outcomes reported by Nelson et al. (2014), however, the most likely increasing or stable real prices of agricultural commodities can be expected up to 2050 . The main reasons for the increasing real prices of food and agricultural products are increasing population, income growth, and shifts in food diets towards livestock products in countries with rapidly increasing incomes and low initial share of livestock products. This reasoning is also shared by Martin et al. (2008), showing increasing specialization in agricultural production between different countries and production regions as well.

A strong warming of the global climate is more likely to result in higher prices for agricultural products than mild warming, due to the fact that strong warming is particularly challenging and difficult for many important production regions in Europe and globally, such as Southern Europe, Australia, and Latin America (Olesen \& Bindi 2002). Strong warming also poses challenges to crop production in northern Europe (Rötter et al. 2013). Low or moderate warming of the global climate, in turn, probably means higher yield potential in northern Europe, while global challenges to food production are then also less severe than in the case of strong warming. This means that prices of agricultural products increase less in low warming scenarios than in scenarios of strong warming. For this reason, global prices are driven by climate change itself, future demand, and the supply response of global agriculture.

Agricultural and other policies and societal issues affect agricultural development. For example, environmental legislation and agricultural policy schemes, and their flexibility in coping with the changing climate and demand conditions, may have a major effect on the ability of agricultural systems to cope with the altered local production conditions and global prices.

\section{Price and crop yields scenarios}

All these findings described above, suggesting the importance of future prices and flexible policy schemes for agricultural adaptation and crop yield development, give a reason for constructing the future scenarios for prices and crop yields. A small country perspective is taken here, assuming that global or European prices are not affected by domestic production. Altered production in small agricultural producer countries such as Finland and other northern countries in Europe cannot influence European or global prices. In this context, it is reasonable to evaluate agricultural development assuming exogenous EU level prices, which, however, largely determine the agricultural commodity prices in all the EU member states. 
A baseline and three socio-economic scenarios of agricultural change have been selected for 2015-2050 (Table 1). Agricultural commodity prices stay at the baseline level in the little and moderate adaptation scenarios, but increase significantly already by 2030 in the successful adaptation scenario. Nelson et al. (2014) compared the recent outcomes of 9 global trade models and found prices of agricultural commodities varying between $-5 \%$ and $+30 \%$ from the baseline levels, depending on the model. Thus, the prices in the different scenarios below are consistent with the price range found in Nelson et al. (2014). However, decreasing real prices, though less likely than stable or increasing real prices, are not considered in this study. This is because less than $10 \%$ of the trade model outcomes studied by Nelson et al. (2014) suggested negative change in the aggregate agricultural price index, and because the modelled impacts of a scenario with a $5 \%$ reduction in prices were very similar to the impacts of the scenarios assuming baseline prices.

Table 1. Yield and price -scenario specifications for years 2014-2050, compared to the baseline

\begin{tabular}{|c|c|c|c|c|c|}
\hline & $\begin{array}{c}\text { Successful } \\
\text { adaptation, } \\
\text { very high } \\
\text { prices (SuA_- } \\
\text { VHP) }\end{array}$ & $\begin{array}{c}\text { Moderate } \\
\text { adaptation } \\
\text { (MoA) }\end{array}$ & $\begin{array}{c}\text { Little } \\
\text { adaptation } \\
\text { (LiA) }\end{array}$ & $\begin{array}{c}\text { Little } \\
\text { adaptation, } \\
\text { high prices } \\
\text { (LiA_HP) }\end{array}$ & $\begin{array}{c}\text { No adaptation, } \\
\text { high prices } \\
\text { (NoA_HP) }\end{array}$ \\
\hline $\begin{array}{l}\text { Crop yield, until } \\
2050\end{array}$ & $+30 \%$ & $+10 \%$ & $-10 \%$ & $-10 \%$ & $-20 \%$ \\
\hline $\begin{array}{l}\text { Cereals prices, from } \\
\qquad 2030\end{array}$ & $+30 \%$ & $0 \%$ & $0 \%$ & $+10 \%$ & $+10 \%$ \\
\hline $\begin{array}{l}\text { Meat prices, from } \\
2030\end{array}$ & $+15 \%$ & $0 \%$ & $0 \%$ & $+5 \%$ & $+5 \%$ \\
\hline $\begin{array}{c}\text { Dairy product } \\
\text { prices, from } 2030\end{array}$ & $+7.5 \%$ & $0 \%$ & $0 \%$ & $+2.5 \%$ & $+2.5 \%$ \\
\hline
\end{tabular}

The Baseline. In this "business as usual" scenario, the unchanged yields and agricultural policy of 2013-2014 are assumed. Future prices of agricultural outputs are not assumed to change from the prices of 2008-2013; they are, in fact, very close to the EU prices projected by OECD-FAO agricultural outlook 2013 (www.agri-outlook.org). Unchanged 2013 policy is assumed in 2014-2050. 90\% of CAP pillar 1 payments (approx. EUR 550 million annually in Finland) are paid on a per hectare basis, fully decoupled from crop choice and production. Payments for less favoured areas (LFA) are paid on a hectare basis irrespective of crop choice, but include higher payments for livestock farms than for crop farms. LFA payments provide an implicit incentive for extensive production. Agrienvironmental payments include explicit elements aimed at water protection and biodiversity conservation, but effectively restricts fertilization levels at the current levels. In total, CAP pillar 2 payments (LFA and agri-environmental payments combined) amount to approx. EUR 800 million annually. Approx. $10 \%$ of CAP pillar 1 payments are coupled to production through dairy cow and bull premiums, paid mainly in support regions $A$ and B. Nordic Aid, approx. EUR 500 million per annum, fully paid from the national state budget, according to the regulations approved at EU level, provides milk and beef payments coupled to production, as well as some minor crop-specific payments in C support regions C1, C2, C2P, C3, and C4. Milk payments, as part of the Nordic Aid scheme, in support regions $A$ and $B$ are 3 cents/litre and 7-14 cents/litre in the $C$ support regions. There are separate budgetary constraints for the milk and beef payments, respectively, in support regions $A$ and $B$, and $C$ regions, respectively. This means that coupled support does not increase, but the support paid per unit decreases with increasing production. The aim of the coupled payments is to maintain existing, historical production levels in A and B; and Csupport regions separately, without leading to any expansion of production. A more detailed presentation of the support payments is easily accessible in Niemi and Ahlstedt (2012). Domestic demand for agricultural products is kept at the 2012-2013 level.

The following price-yield scenarios are constructed in such a way that increased crop prices and implied increase of feed costs of livestock production are assumed to result in increasing prices of livestock products as well, in order to compensate the increase of marginal costs of production for livestock producers. This kind of assumption is justified because it represents marginal cost pricing on competitive markets. Approx. $50 \%$ of the production costs of meat production, and $25 \%$ of the production costs of dairy milk production in the EU (including main producer countries such as Germany), are feed costs (own calculations; Luke 2015). It is reasonable to assume that a $10 \%$ increase in feed crop prices implies a $5 \%$ increase in meat and egg prices. However, in the case of dairy milk production, a $10 \%$ increase in purchased feed prices implies only a $2.5 \%$ increase in the producer price of milk. This assumption is reasonable as well in the case Finland (with $25-30 \%$ higher producer prices of milk compared to the EU average), since $45 \%$ of the dry matter content of a dairy feed diet is provided by non-roughage feeds (Huhtamäki 2014), such as concentrates and protein supplements, and feed grain, mostly purchased outside the farm. Roughage feeds are almost always produced using the farmer's own labour and machinery or purchased from close sub-contractors. Thus the marginal costs of roughage are little affected by the increased prices of purchased feeds. 
Overall, the shift of livestock product prices following the increased crop prices is assumed to be compensated to livestock producers through competitive markets, which is a reasonable assumption in the case of competitive markets and long-term economic adjustments. Domestic food demand, which is relatively stable in high-income countries such as Finland, is assumed to remain unchanged.

Successful adaptation, very high prices (SuA_VHP). In this optimistic scenario, crop yields increase gradually by 30\% from the 2000-2012 average yield levels of cereals and grasslands (annual increment 0.9\% of the 2000-2012 average yield) and by 60\% from the 2000-2012 average yield levels for oilseeds and winter cereals in 2015-2050. Prices, policies, research and development imply an effective adaptation, including new cultivars that are suitable for a longer growing season. Higher crop yield levels are also driven by liming which brings the soil pH up and thus in the context of Finland directly promotes crop yields. Increased fungicide use for cereals (assumed to be allowed by the agri-environmental policy), and drainage and soil structure investments are assumed to be encouraged by higher crop prices and allowed by the policy. Drought problems are mitigated by new cultivars that are better suited to the changed climate. New cultivars and their appropriate management provide relatively high yield gains of oilseeds and winter cereals.

Cereal prices increase by $30 \%$, meat prices by $15 \%$ and milk product prices by $10 \%$ in this very optimistic scenario. Nitrogen $(\mathrm{N})$ fertilization increases by almost $30 \%$ due to the nutrient needs of plants that increase with the increasing yields. The costs of grain drying and handling per ha increase by $30 \%$ as well, due to $30 \%$ higher crop yields. This is because the current need for grain drying, implying costs of 14 eur ton ${ }^{-1}$ (or 53.2 eur ha-1 at average 3.8 ton ha $^{-1}$ crop yield level of barley; ProAgria 2010, p. 142) is not likely to decrease as a result of climate change since increased precipitation during the growing period is predicted by climate models for northern Europe (Lehtonen et al. 2014b). Prices of $\mathrm{N}$ fertilizers, which are in greater demand in this scenario, increase by only $10 \%$. The great increase in crop yields in this scenario is mainly driven by $30 \%$ higher EU level cereals prices even by 2030 , compared to the baseline. High prices are also combined with policies allowing higher fertilization. Nutrient balances of $\mathrm{N}$ and phosphorus (P) per crop decrease slightly and remain close to the baseline level (2007-2013 levels).

Reaching 30\% higher crop yields, compared to the baseline with average crop yields for 1995-2012, is challenging but possible, at least in theory. New cultivars of cereals and grass may provide significant yield gains, but such gains are specific to climate scenario, crop and soil type. Rötter et al. (2013) provide some estimates of the contribution of "future cultivars" to the crop yield of barley. However, in this scenario it is merely assumed that future cultivars facilitate crop yield responses of the specific management options (below) when aiming for the $30 \%$ increase in yields up to 2050. These management options include increased $\mathrm{N}$ fertilization, increased liming and crop protection. It is also assumed that renewed/improved drainage costs, necessary to ensure sufficient water retention of the soil, are largely covered by agricultural support payments. These, otherwise largely decoupled from production decisions in the EU, require farmland to be kept in "good agricultural condition", referring to sufficient drainage and other relevant conditions.

Approx. 3-5\% higher cereals yields can be attained by $10-20 \%$ higher use of $\mathrm{N}$ fertilizer (economically optimal increase in N fertilization and the resulting increase in crop yield are crop-specific; Lehtonen 2001). Increased liming , which brings up soil pH from average levels of 5.5-6.5 up to 6.0-7.0, could provide a 10-15\% increase in yields. Introducing fungicide use for cereals may increase yields by $10-15 \%$ compared to non-use of fungicides (Purola 2013). The costs of these measures can be directly taken into account in this study, but not the possible costs of new cultivars better attuned to future climate, needed to realize the 30\% higher yields in $2015-2050$.

The direct cost implications of $30 \%$ higher yields for a farmer include, at a minimum, the increased costs of fertilization (approx. 50 eur ha $\left.{ }^{-1}\right)$, grain drying (16 eur ha-1), and increased liming (10 eur ha-1 year $\left.{ }^{-1}\right)$. These cost estimates are compatible with ProAgria (2010) calculations on the necessary inputs per ha when aiming to yield levels of 4 and 5 tons per ha. In total, 76 eur ha ${ }^{-1}$ higher costs are well covered by the increased value of output per hectare (180 eur ha ${ }^{-1}$, calculated at a price of 150 eur ton $^{-1}$ ) because of $30 \%$ higher yields.

While the increased use of liming is allowed by current policy settings, there are upper limits for $\mathrm{N}$ fertilization in the Agri-Environmental scheme, which is likely to restrict or at least discourage significant yield gains such as $30 \%$ (Peltonen-Sainio et al. 2015). It is uncertain to what extent the increasing $\mathrm{N}$ fertilization, even if implying a non-increasing $N$ balance, is compatible with future agri-environmental policies and, for example, the Baltic Sea Action Plan (BSAP), reaching up to 2021 (HELCOM 2013). Nevertheless, this scenario represents a state of the world where agricultural commodity prices are high, and farmers' attempts to achieve higher yields are allowed by policies. 
Moderate adaptation (MoA). Yields increase linearly by an amount which is $10 \%$ of the $2000-2012$ yield level up to 2050 (annual increment $0.25 \%$ of the $2000-2012$ average yield). Fertilization increases by $10 \%$ as well, to safeguard the nutrients needed in plant growth. Prices are the same as in the baseline, but policies (agri-environmental scheme currently effectively restricts fertilization levels) are adjusted to allow a $10 \%$ increase in fertilisation. Moderate market prospects and the possibility of slightly increased fertilization imply liming (though less than in the successful adaptation scenario) in order to realize increasing yields on specialized cereals farms, which also utilize new cultivars. The overall policy environment, however, does not encourage a large group of part-time unspecialized farmers in such investments. Consequently, the crop yields increase by $10 \%$, and the increased value of the crop output covers the implied costs (this can be verified by using the same kind of calculations as in the SuA scenario above)

Little adaptation (LiA). Adaptation is rare due to increased inflexibility in policy rules, for example, an agri-environmental scheme with stricter fertilization limits. Some individual farms could avoid cereals yield reductions with the help of some adaptations based on new cultivars, fungicide use and liming, despite non-increasing fertilisation. However, adaptations at the farm and crop level are rare, and yields decrease by $10 \%$ on both cereals and grasses, which is the opposite change in yields compared to the "Moderate adaptation" -scenario. Fertilisation does not, however, decrease, since no change in real prices is expected in this scenario in which agricultural policy does not encourage productivity improvements in crop production. Thus, crop yields decrease by $10 \%$ in this scenario.

For the purposes of covering a pessimistic view of crop yield development, two "worse-case" scenarios were specified, with $10 \%$ higher crop prices compared to the baseline but with either small (yields of -10\%) or non-existent (yields of $-20 \%$ ) adaptation:

Little adaptation, high prices (LiA_HP; yields of $-10 \%$, crop prices $+10 \%$ )

No adaptation, high prices (NoA_HP; yields of $-20 \%$, crop prices $+10 \%$ ).

In both of these two scenarios, decreasing yields are realized despite slightly increasing commodity prices. This means a major failure in adaptation to climate and market changes, at least from the point of view of crop yields. Such a development may be realized, despite the incentives provided by the $10 \%$ higher crop prices, in the case of severe difficulties and constraints for adaptation: if policies restrict or discourage maintaining yields for instance through restricting sufficient fertilization and crop protection, or if regional climates in the main production regions in Finland turn out to be more challenging than expected, and if the current cultivars, vulnerable to climate change, are used instead of new ones better suited for future climate conditions. Some crop modelling results related to current barley cultivars, especially on drought-prone sandy soils (e.g. Rötter et al., 2013), suggest such negative yield developments.

\section{Economic agricultural sector model DREMFIA}

Changes in regional level agriculture throughout Finland under these scenarios are evaluated using an economic agricultural sector model DREMFIA. The model simulates production and foreign trade of agricultural commodities, as well as land use (areas under crops and set aside) and production intensity (fertilization, manure use) annually from 1995 up to 2020 and produces a steady state static equilibrium for 2030, 2040 and 2050. The model assumes rational economic behaviour and competitive markets, replicates realized production and land use 19952012, and produces consistent future development paths of agriculture (see Lehtonen 2001 and 2013 for details).

Four main areas are included in the model: Southern Finland, Middle Finland, Ostrobothnia (the western part of Finland), and Northern Finland (Fig. 1). Demand and foreign trade is determined at the level of the main regions. The products move between the main regions to cover the demand of each main region at a certain transportation cost. Since the model is very exact in terms of agricultural policy, the main regions are further divided into sub-regions according to regional disaggregation specific to agricultural support payments and related specific conditions. Production is thus determined at the level of each of the 17 sub-regions (Figure 1 shows 14 regions, 3 small regions not shown). More details of the model are available in Lehtonen $(2001,2013)$. 


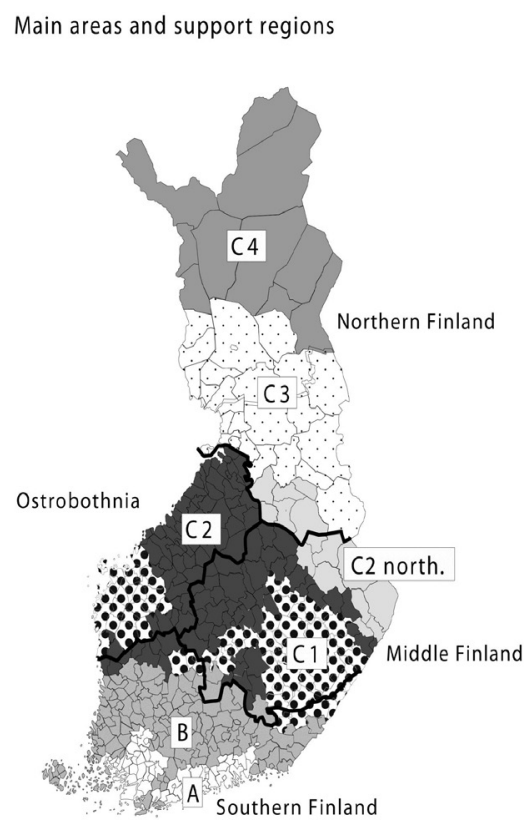

Fig.1. Spatial aggregation of the DREMFIA sector model. The 4 main regions are divided into support-regions (A, B, C1, C2, C2north., C3, C4) based on agricultural policy: Southern Finland -support regions $A, B, C 1, C 2$; Middle Finland -support regions B, C1, C2, C2 North; Ostrobothnia -support regions $\mathrm{C} 1$ and $\mathrm{C} 2$; Northern Finland -C2 North, C3, C4.

Demand in each main region is covered by the production in its own sub-regions, by transport from other regions, or by imports from abroad. The model is solved so as to achieve the most economic outcome, i.e. the one maximizing producer and consumer surplus. The underlying hypothesis is that producers engage in profit-maximizing behaviour and consumers engage in utility-maximizing behaviour in competitive markets. Decreasing marginal utility of consumers and increasing marginal cost lead to the production and foreign trade levels where the marginal cost of supply is equal to market prices. Each region specializes in products that provide the greatest profitability, taking into account the profitability of production in other regions, import prices, and consumer demand. The use of different production resources, including farmland, is optimized, taking into account differences in resource quality, technology, and costs of production and transportation. Domestic and imported products are imperfect substitutes, i.e. there are differences, even if limited, between the prices of domestic and imported products. Substitution elasticities and price elasticities of demand are adjusted in the model calibration in order to validate model prices to observed prices.

Prices of $\mathrm{N}$ fertilizer and crops affect fertilization levels. If crop prices increase, farmers in each region increase fertilization as long as the value of increased crop yield is higher than the value of increased fertilizing. Crop-specific $\mathrm{N}$ response functions determine the economically optimal $\mathrm{N}$ fertilization and crop yields. If manure from livestock is available, less commercial fertilizers are needed to reach the economically optimal level of fertilization. The $P$ content of the manure of different animals is taken into account. Non-negative P balance is ensured in the model, i.e. inorganic fertilisers provide additional $\mathrm{P}$ if the $\mathrm{P}$ balance turns negative in the model.

The yield and price scenarios are given in the model in the form of (1) future crop yields -the model adjusts fertilization according to the needs of plants to reach the specific yield levels; different fertilization response functions are used for different crops (Mitscherlich function for barley, wheat, oats, mixed cereals and peas, and quadratic function for rye, potatoes, sugar beet, hay, silage, green fodder and oilseeds; cf. Lehtonen 2001); (2) future prices (EU prices), which affect the use of inputs, crop yields and changes in the levels of production and foreign trade. Increased yields mean increasing the intercept of the response functions while keeping first and second order parameters unchanged, due to lack of published evidence of such parameter changes related to the chosen climate scenarios. This is also means that nitrogen use efficiency (NUE), i.e. the share of $\mathrm{N}$ utilized by the plants is assumed to be unchanged. Altered yields and prices imply changes in the regional allocation of both livestock and crop production, to reach competitive production structure and supply (also changing imports and exports) with respect to the food demand which is assumed to stay unchanged from the 2012-2013 level.

The baseline, an important point of comparison for the specified scenarios presented above, is rooted in the model through a multi-phase validation process. Primarily, known statistical data from official agricultural statistics 19952013 is used extensively, as well as some selected empirical data from research databases for the parameter values in different production functions determining feed use and yield levels of animals, fertilizer use and crop yields. 
Available data on milk quota prices, land rental values, value and quantity of inputs are also used in the model validation. Some few model-specific behavioural parameters, which have no or few exact estimates or no correspondence in the literature or known data sources, have been adjusted so that the model very closely replicates the historically observed development of production, land use and prices. Such calibration parameters are (1) substitution elasticities and price elasticities of demand in the demand functions, as well as (2) the farm-type specific savings rates, and (3) the propensity to invest in larger farm size on dairy farms. Endogenous structural and technical change in the dairy sector can be validated, using a simple unique combination of the savings rate and propensity to invest, to follow the development of the farm structure statistics (Lehtonen 2001, 2013).

Equilibrium properties of the model (increasing marginal costs in terms of production quantity, reducing the marginal utility of consumers) stabilize the overall production very close to the observed production quantities at the whole country level and in the four main regions. Region-specific budget limits imposed on production support for milk and bovine animals also contribute to the production allocation. The observed and simulated production levels at the national level are given in Table 2. The model is validated to replicate known production patters, using data from official agricultural statistics and various technical and farm level data, as well as through calibrating unobserved parameters (i.e. the propensity to invest, savings rate, substitution elasticities). However, when comparing the model outcome to the observed production development in 2008-2012, some relatively small deviations still occur (Table 2). Grassland area in the model is less than the observed area due to the fact that horses, lambs and reindeer are not included in the model. Beef and milk production are slightly higher in the model solution than in reality mainly because of the stagnation of the milk yields of dairy cows in 2008-2012, not fully explained by the increased prices of concentrate feeds taken into account in the model. In other words, the increasing milk yield trend is slightly less stagnated in the model outcome than in reality. Obvious reasons for the observed stagnation of the milk yields per cow have been identified as 1) problems in cow fertility and feed diet optimization on large, newly established large scale-dairy farms; 2) a simultaneous exit of small farms with high milk yield output, and 3 ) poor quality of silage grass harvests in some individual years. These factors are difficult to include in the model. Further examples of the comparisons between the model results and reality are available in Lehtonen (2013).

Table 2. Production quantities, crop cultivation areas and farm income in the baseline scenario and reality ("observed": official agricultural statistics, http://www.luke.fi/en/statistics/ ); 5-year average 2008-2012. The grassland area is smaller in the DREMFIA baseline than in reality, since horses, lambs and reindeer (users of roughage) are not included.

\begin{tabular}{ccccccccc}
\hline & $\begin{array}{c}\text { Cereals } \\
\text { (1000 ha) }\end{array}$ & $\begin{array}{c}\text { Grasslands } \\
\text { (1000 ha) }\end{array}$ & $\begin{array}{c}\text { Milk yield } \\
\text { per cow } \\
\text { (litres) }\end{array}$ & $\begin{array}{c}\text { Milk } \\
\text { production } \\
\text { (million } \\
\text { litres) }\end{array}$ & $\begin{array}{c}\text { Beef } \\
\text { (million } \\
\text { kg) }\end{array}$ & $\begin{array}{c}\text { Pigmeat } \\
\text { (million kg) }\end{array}$ & $\begin{array}{c}\text { Poultry meat } \\
\text { (million kg) }\end{array}$ & $\begin{array}{c}\text { Farm } \\
\text { income } \\
\text { (million } \\
\text { eur) }\end{array}$ \\
\hline DREMFIA & 1132.6 & 605.3 & 7.867 & 2258.5 & 82.4 & 203.7 & 95.1 & 769 \\
$\begin{array}{c}\text { Observed } \\
\begin{array}{c}\text { Relative } \\
\text { difference }\end{array}\end{array}$ & 1144.7 & 656.3 & 7.850 & 2200.7 & 81.6 & 204.2 & 100.2 & 732 \\
\hline
\end{tabular}

\section{Results}

\section{Agricultural production and land use development in Finland}

The results of the DREMFIA sector models include two main dimensions: 1) changes in production intensity (fertilization, crop yields and nutrient balances) per crop, and 2) overall livestock and crop production, including related land use change of agricultural land. Both these aspects, sometimes called as "intensive" and "extensive" margins, consistently integrate in the DREMFIA sector model simulating domestic production, exports and imports of agricultural products. The model was run for all yield and price scenarios presented above.

First, the scenarios enter the crop yield response functions in which crop yields are specified through $\mathrm{N}$ use. At given prices of crop output and $\mathrm{N}$ fertilizer, the optimal use of $\mathrm{N}$ and crop yield is calculated for each crop. Let us summarise the crop-specific fertilization and yield changes as follows. We use barley, the most cultivated cereal crop, as a representative example of the fertilization and crop yield changes. We present the $\mathrm{N}$ fertilization and yield levels of barley in southern Finland (support region B which is the most important region for barley production) in Figure 2, and the resulting yield (Fig. 3) and $\mathrm{N}$ balance (Fig. 4). 


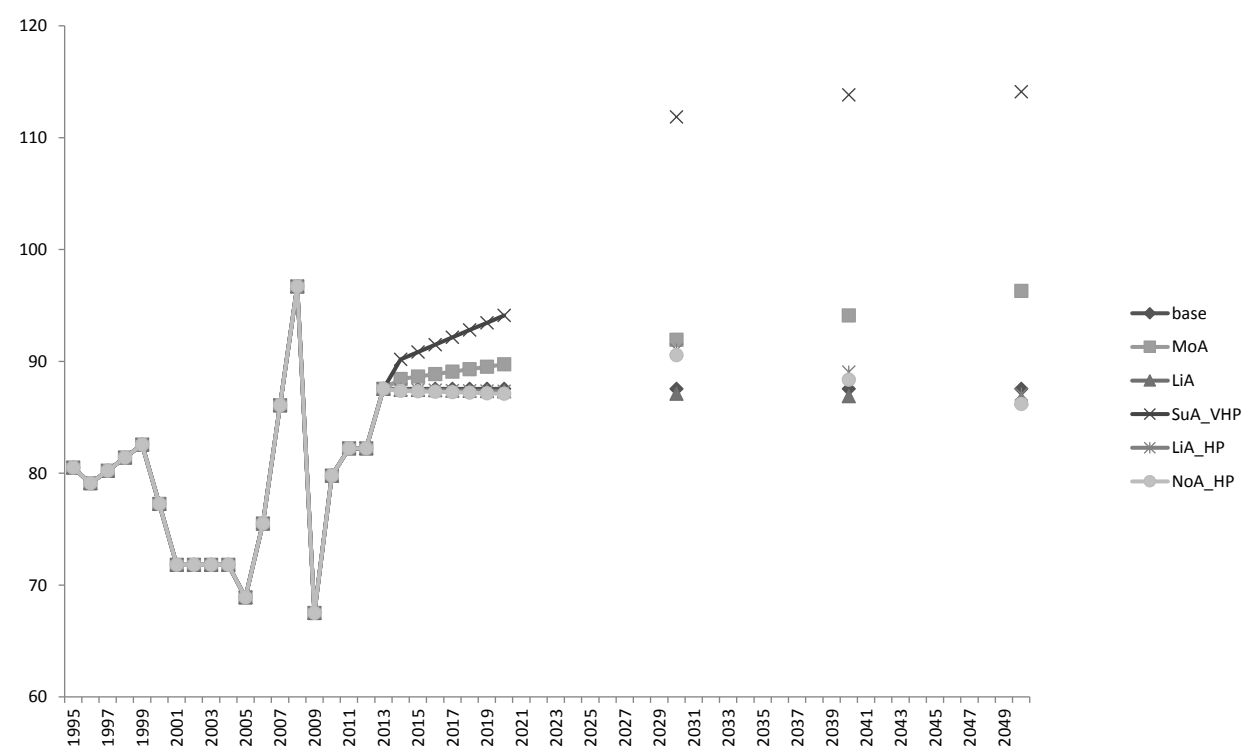

Fig. 2. Nitrogen fertilisation for barley $\left(\mathrm{kg} \mathrm{N}^{-1}\right)$ in different scenarios, southern Finland, support region $\mathrm{B}$. Base $=$ Baseline; $\mathrm{MoA}=$ Moderate adaptation (yields $+10 \%$ ); LiA $=$ Little adaptation (yields $-10 \%$ ); SuA_VHP $=$ Successful adaptation, very high prices (yields $+30 \%$, crop prices $+30 \%$ ); LiA_HP = Little Adaptation, high prices (yields $-10 \%$, crop prices $+10 \%$ ); NoA_HP $=$ No adaptation, high prices (yields $-20 \%$, crop prices $+10 \%$ )

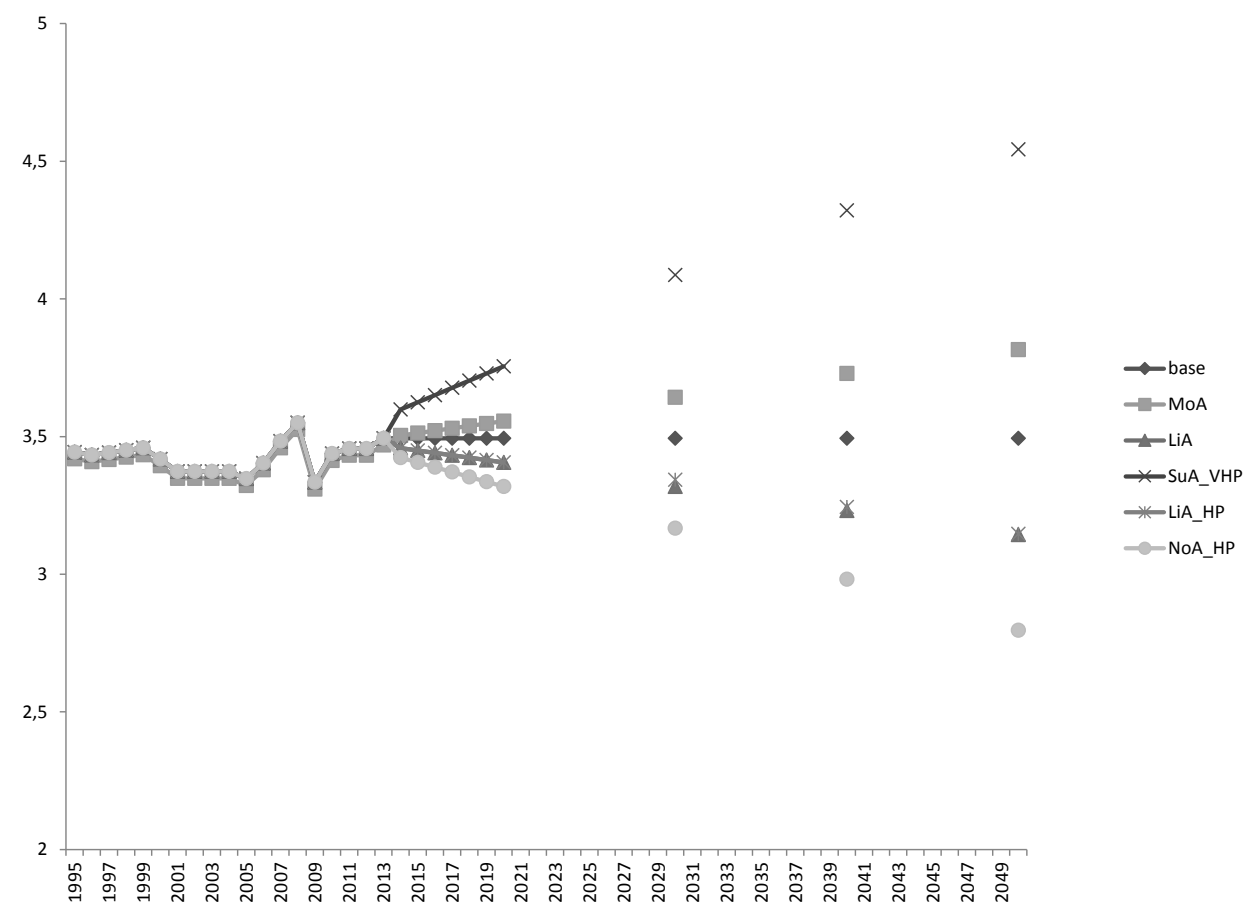

Fig. 3. Yield level for barley $\left(\mathrm{kg} \mathrm{Nha}^{-1}\right)$ in different scenarios, southern Finland, support region $\mathrm{B}$. Base=Baseline; MoA=Moderate adaptation (yields $+10 \%$ ); LiA = Little adaptation (yields $-10 \%$ ); SuA_VHP $=$ Successful adaptation, very high prices (yields $+30 \%$, crop prices $+30 \%$ ); LiA_HP $=$ Little Adaptation, high prices (yields $-10 \%$, crop prices $+10 \%$ ); NoA_HP $=$ No adaptation, high prices (yields $-20 \%$, crop prices $+10 \%$ )

The increasing yield potential takes place gradually over 2014-2050 in the scenarios, while price changes take place already in 2020-2030. This implies that $\mathrm{N}$ fertilization increases faster than the yields. Furthermore, the empirically validated $\mathrm{N}$ response functions suggest that the relative increase in $\mathrm{N}$ fertilization is larger than the resulting increasing crop yields. This, in turn, results in smaller profits per ha from increased yields than suggested by increased crop yields as such, and increasing $\mathrm{N}$ balances. 


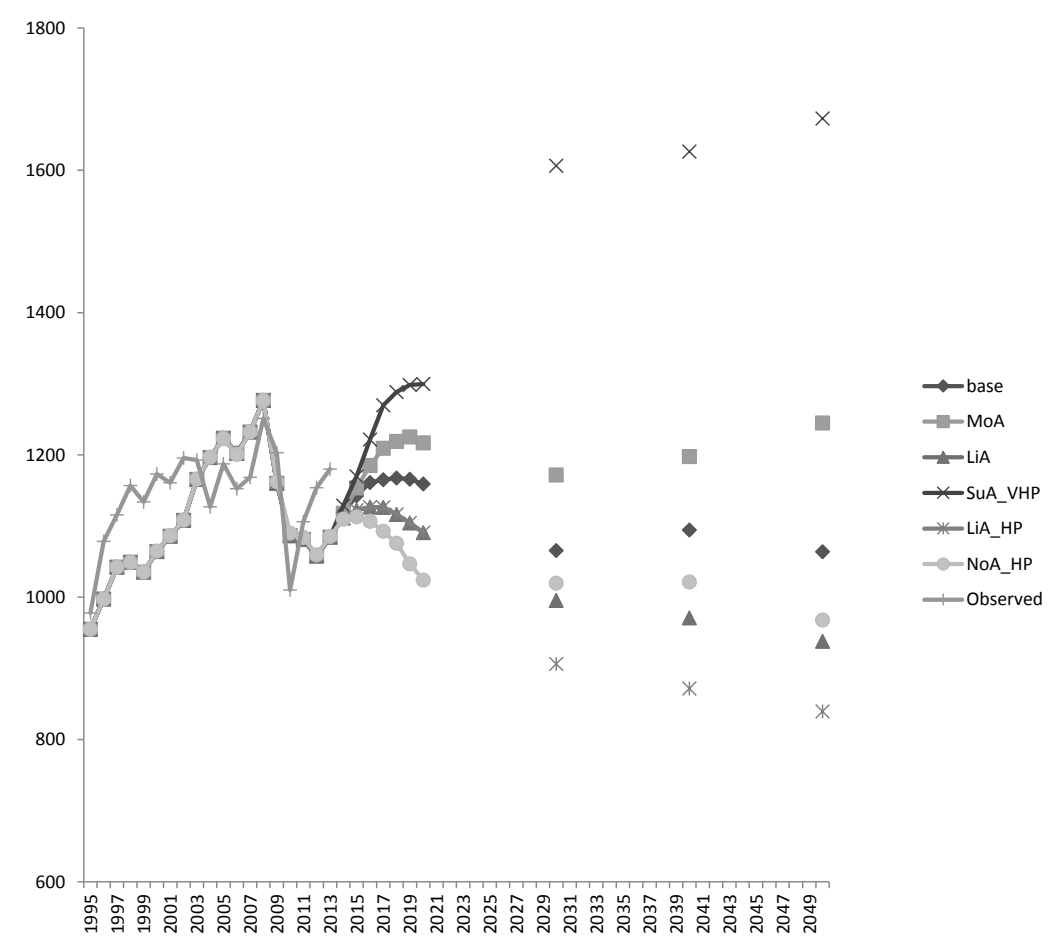

Fig. 4. Land area under cereals (1000 ha). Base = Baseline; MoA = Moderate adaptation (yields +10\%); LiA = Little adaptation (yields $-10 \%$ ); SuA_VHP = Succesful adaptation, very high prices (yields $+30 \%$, crop prices $+30 \%$ ); LiA_HP $=$ Little Adaptation, high prices (yields $-10 \%$, crop prices $+10 \%$ ); NoA_HP $=$ No adaptation, high prices (yields $-20 \%$, crop prices $+10 \%)$

Next, let us summarise the land use and crop production results. More land area is allocated to cereals in the scenario of successful adaptation (Fig. 4). Together with the yield increase by $30 \%$, this means that overall cereals production increases by almost $90 \%$ from the average level of 3.8 million tons in 2000-2013 (Fig. 5). In the moderate adaptation scenario (MoA), crop yields increase by $10 \%$ but the area under cereals stays close to 1.2 million hectares (the average in 2002-2013 is a little less than 1.2 million ha). Overall production of cereals decreases at least slightly in all the other scenarios assuming no increase in crop yields, including baseline. Low yields, for example, the almost $20 \%$ lower yields in scenario NoA_HP, on the other hand, lead to a higher cereals area than in the scenario where crop yields decrease by only $10 \%$. This is because the higher prices compared to the baseline lead to significantly reduced dairy and beef production (Table 3) but, however, still keep cereals production somewhat profitable. This means that cereals become relatively more competitive compared to grass. Since there is land available (there has been approx. 200-300,000 ha under set aside in 2008-2013), more land is allocated under cereals.

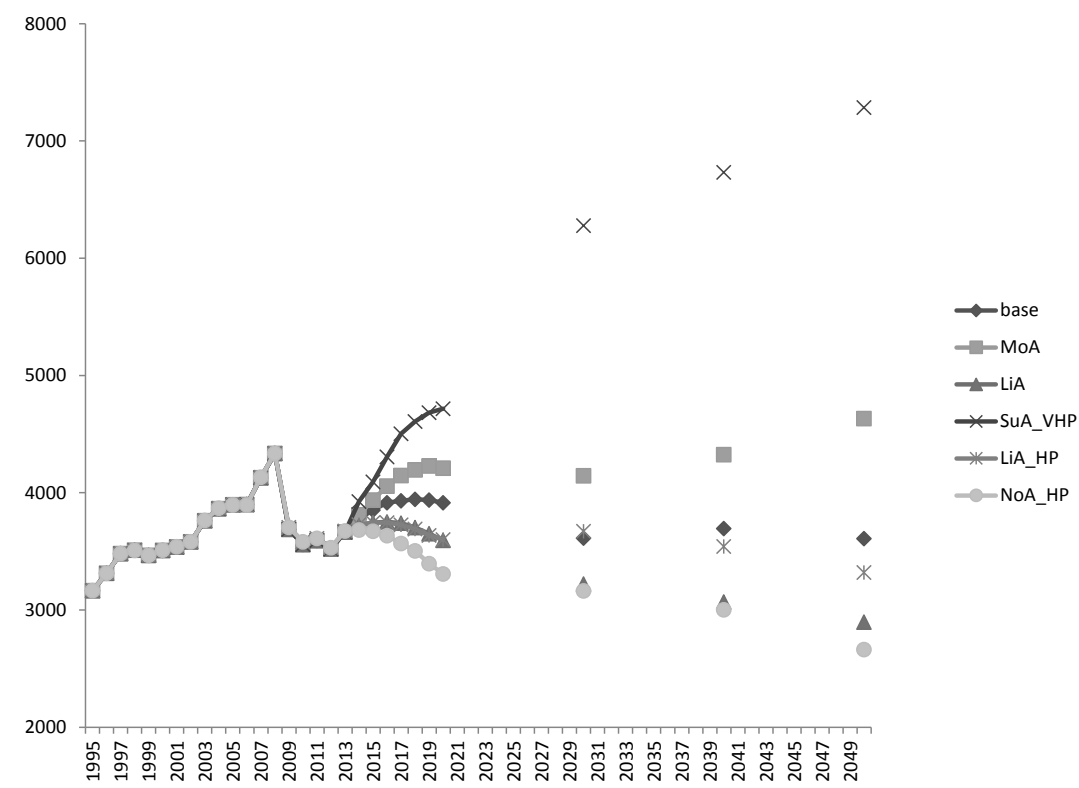

Fig. 5. Cereals production (1000 tons). Base = Baseline; MoA = Moderate adaptation (yields +10\%); LiA = Little adaptation (yields $-10 \%$ ); SuA_VHP = Successful adaptation, very high prices (yields $+30 \%$, crop prices $+30 \%$ ); LiA_HP $=$ Little Adaptation, high prices (yields $-10 \%$, crop prices $+10 \%$ ); NoA_HP $=$ No adaptation, high prices (yields $-20 \%$, crop prices $+10 \%$ ) 
Table 3. Simulated livestock production (meat in 1000s tons, milk in mill. litres) and farm income (eur mill.) in 2050 [Observed average values for 2008-2012 are given for comparison]

\begin{tabular}{lcccccc}
\hline & $\begin{array}{c}\text { Baseline } \\
\text { 2050 }\end{array}$ & MoA 2050 & LiA 2050 & $\begin{array}{c}\text { SuA_VHP } \\
\text { 2050 }\end{array}$ & LiA_HP 2050 & $\begin{array}{c}\text { NoA_HP } \\
2050\end{array}$ \\
\hline Beef [2008-2012: 81.6] & 80.1 & 81.9 & 77.5 & 81.7 & 76.7 & 73.4 \\
Pork [2008-2012: 204.2] & 158.2 & 163.0 & 153.7 & 176.5 & 161.1 & 153.4 \\
Poultry [2008-2012: 100.2] & 82.3 & 82.8 & 81.7 & 84.7 & 82.8 & 82.0 \\
Milk [2008-2012: 2200.7] & 2011.3 & 2108.8 & 1895.7 & 2565.4 & 1975.5 & 1845.8 \\
Farm income [2008-2012: 733.2] & 547.1 & 625.6 & 478.9 & 1284.1 & 573.0 & 489.1 \\
\hline
\end{tabular}

Livestock production is relatively stable in all scenarios (Table 3). This implies a stable demand for feed grain. Dairy and beef production is stabilised by some national and EU CAP payments coupled to production, and there are budget limits for these specific production linked subsidies. If the total sum of each category of support payments coupled to production exceeds the budgetary limit, the support level per litre of milk is reduced in order to keep the support payments within the budgetary limits. Despite this, some expansion of approx. $15 \%$ from the 2013 production level takes place however in dairy production in the successful adaptation scenario (Fig. 6).

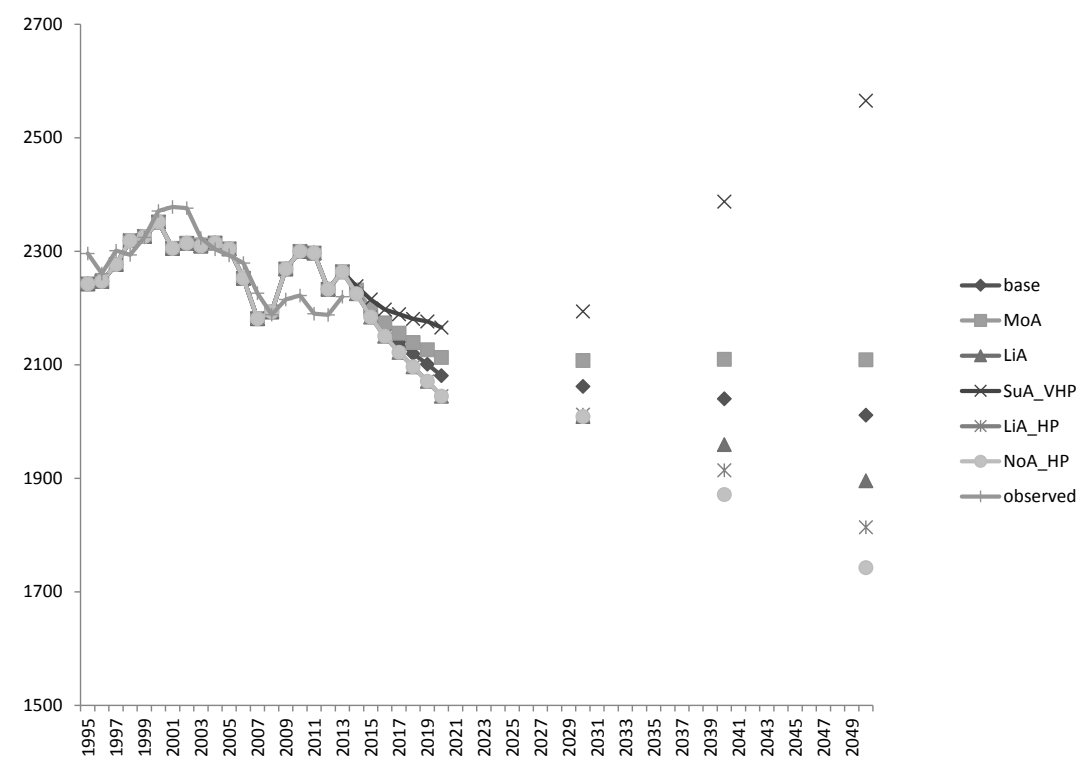

Fig. 6. Milk production (million litres) in Finland. Base $=$ Baseline; $M o A=$ Moderate adaptation (yields +10\%); LiA = Little adaptation (yields $-10 \%$ ); SuA_VHP = Successful adaptation, very high prices (yields $+30 \%$, crop prices+30\%); LiA_HP = Little Adaptation, high prices (yields $-10 \%$, crop prices $+10 \%$ ); NoA_HP $=$ No adaptation, high prices (yields $-20 \%$, crop prices $+10 \%$ ). Observed $=$ milk production, according to official statistics

The $30 \%$ higher crop yields lead to a significant reduction in the production costs of roughage (including the logistic costs of manure and grass silage), and imply an approx. $25 \%$ reduction in the grassland area. This also facilitates a significant expansion of milk production in the most competitive dairy regions such as Ostrobothnia and part of Middle Finland. The increase in the competitiveness of milk production in the SuA scenario is further enhanced by the re-allocation of milk production to the most competitive regions. While pig and poultry farms are relatively more dependent on purchased feed, dairy becomes relatively more favoured in the successful adaptation scenario. The reduced need for the overall grassland area, however, frees up some land for increased cereals production, used as feed in pork and poultry production, This is the reason why pork production increases eventually by $12 \%$ and replaces a large part of imported pork (more than $20 \%$ of pork is imported in the baseline). Poultry meat production, however, does not increase much in the successful adaptation scenario, since the imports cover only approx. 10\% of domestic poultry meat consumption (in 2013 and in the baseline). Beef production is slightly less in the SuA scenario than in the MoA scenario, despite the higher grass yield level in the SuA scenario, because of the relatively low beef prices, already in the baseline scenario, which do not cover even the feed costs in the baseline. 
The uncompetitive relative position of beef production relative to dairy, pork and poultry meat production, even after the increased crop yields and prices by $30 \%$ in the SuA scenario, leads to a significant reduction in suckler cows. Thus, the expansion of dairy and reduction of suckler cows leads to only slightly increased beef production on the SuA scenario, compared to the baseline.

Decreasing crop yields imply lower profits for livestock production. Consequently, dairy and beef production volumes are affected so that $5-10 \%$ less beef and milk is produced, and approx. 5-10\% less grass forage is needed, if lower yields realize (-10-20\% yield changes in the LiA_HP and NoA_HP -scenarios).

Higher crop yields lead to an expansion of the cereals area and a decrease in the grassland area. Larger cereals areas and reduced areas under grasslands are the likely outcomes of moderate or successful adaptation. This change is more pronounced in areas where the share of grasslands is currently high, i.e. middle Finland and Northern Finland, while in Southern Finland and the Ostrobothnia region, where the share of grasslands is lower, the relative change in cereals and grassland areas is minor.

The average $\mathrm{N}$ balance over all the cultivated area (excluding set aside land) is slightly increasing in all scenarios, ending up to $8-13 \%$ above the baseline level. This is mainly because of increasing or at least non-decreasing crop prices in the selected scenarios, and partly because of the mechanism in DREMFIA which does not allow a negative $\mathrm{N}$ balance even temporarily, in order to safeguard the availability of plant nutrients. This leads to increasing fertilization per crop, if crop yields increase. Land use change, i.e. the increasing cereals areas and the decreasing grassland areas, does not significantly affect this increasing tendency of nutrient balances, since the $\mathrm{N}$ balances of cereals and grasslands are rather close to each other, according to the model results. $\mathrm{N}$ balances under little or no adaptation scenarios are clearly higher than in more successful adaptation scenarios, especially if crop prices increase.

Total national level farm income increased more than $90 \%$ in the successful adaptation scenario, compared to the baseline. This is mainly because of high prices and increased production, and secondly because of decreased production costs per unit produced due to higher crop productivity. Farm income increased by $14 \%$ in the moderate adaptation scenario, and decreased by $12 \%$ in the little adaptation scenario, until 2050.

\section{Discussion}

Livestock production seems to be sluggishly responding to different yields and price scenarios given. This means that livestock production is not easily increased on a market basis, due to high production costs, compensated by the EU and national payments coupled to production. Their budgetary limits also stabilize dairy and beef production. Thus, crop yield developments mostly affect cereals production volume, and the land area allocated to cereals.

In the very optimistic, successful adaptation scenario, cereals production expanded as much as $90 \%$. This is because there is little market or policy (subsidy) regulation which could inhibit the expansion of production at high prices. There are also abundant farmland resources available, partly freed up from grass, compared to the current level of cereals production. This scenario also implied a $15 \%$ increase in dairy milk production and a $2 \%$ increase in beef production, due to relatively uncompetitive, decreasing suckler cow production, compared to dairy, pork and cereals. Pork production increased by $12 \%$ and poultry meat production by $3 \%$. However, this very successful adaptation scenario can be considered a very optimistic, and most probably rather unrealistic, scenario.

The increase in agricultural production was minor in the moderate adaptation scenario with a $10 \%$ increase in crop yields. Farm income, however, increased by $14 \%$ mainly due to decreased production costs per ton, and a reduced need for cultivated area. Hence, the benefits of any increase in crop yields are likely to realize through a more efficient use of existing resources in agriculture, such as farmland, livestock facilities (animal places available), and labour, rather than through the higher sales value of the increased crop output. Increased crop yields are likely to have more important economic effects in the livestock sector than in the actual crop sector in Finnish agriculture, since most farmland area is used for feed production and manure-spreading purposes. Higher crop yields also imply the possibilities of higher manure-spreading per hectare, and thus reduced logistics costs at livestock farms. Such costs are currently high due to the stringent phosphorous fertilization limits and resulting small volumes of manure that can be spread per hectare.

However it is uncertain whether future agri-environmental schemes and other policy rules allow higher fertilization or greater amount of manure to be spread per hectare. If not, less economic benefit can be obtained from higher crop yields. 
Farm income decreased by $12 \%$ in the little adaptation scenario (yields $-10 \%$ ), until 2050 . This was despite the fact that the support payments coupled to production still maintained a large proportion of existing livestock production in this scenario. More land area was needed for feed production in that scenario, implying higher costs in terms of labour per ton of feed produced, and also increased timeliness costs already high in northern agriculture characterized by short harvesting periods (of silage, in particular). The role of support payments in farm income increased in that scenario. This means that decreasing yields make northern agriculture vulnerable and dependent on policy and support payments.

However, Finnish agriculture seems to cope rather well even with slightly decreasing yields, despite some income loss, due to abundant farmland resources and some national and CAP subsidies coupled to production. Avoiding reductions in crop yields is nevertheless important for maintaining agricultural income in the long-term, even if livestock production is also maintained by national subsidies. Decreasing yields, if realized despite high prices, lead to high nutrient balances and nutrient leaching during more frequent extreme events such as heavy rains, floods and droughts, which become more common in the future climate.

\section{Conclusions}

The results suggest that current high crop and feed production costs, including timeliness costs, the high opportunity cost of labour and various indirect costs related to manure logistics and other farm organisation, can be reduced through higher crop yields. These gains can be higher than the value of increased crop production. Livestock production, especially dairy milk production, may benefit from increasing crop yields in two ways: 1) through reducing costs per unit of grass silage produced, thus contributing to an improved profit margin in milk production, and 2) through increased production in the most competitive regions, currently inhibited by increased land prices and land availability, facilitated by the higher crop yields relieving the land constraints. These adjustments were taken into account in the sector model used in this study. In fact, the relatively higher benefits of higher crop yields for the gross margins in livestock production, as well as the re-allocation of production to the most competitive regions are the main reasons for improved farm income due to increased crop yields. Cereals production, partly independent of livestock production, may expand significantly as well, but cannot provide as much gains in terms of farm income compared to the livestock production.

However, increased cereals production in Finland might result only if both crop prices and yields increase significantly. In such a case, there is an abundance of farmland that can be used in increasing the production of cereals, while expansion of production of other crops and livestock will probably be minor. If higher yields are realized, the relative importance of high labour and machinery costs decreases and leads to improved farm income, but not easily to increased total production.

Nutrient leaching has long been considered to be the most important problem to be addressed by an agri-environmental policy scheme in Finland. If crop prices are high, fertilization may increase relatively more than crop yield. The results suggest that yields should be increased especially in the case of increasing agricultural commodity prices. Higher prices may trigger investments in reaching higher yields, but if such attempts fail, or are inhibited by policies, there will be negative consequences for both farmers and society, due to decreased farm income and increased nutrient surplus.

The results presented are based on assumed non-improving NUE, i.e. the share of fertilizer $\mathrm{N}$ utilized by plants. Increasing $\mathrm{N}$ balances, especially in the case of increasing crop prices, suggests a need to improve NUE. Improvements in NUE through, for instance, new cultivars or improved soil structure, could in the long run reduce the $\mathrm{N}$ balance and nutrient leaching risks.

Based on the results obtained on changed production and farm income, higher crop yields are most likely worth aiming for, if considered at the level of the entire agricultural sector: $10 \%$ higher yields lead to $14 \%$ higher farm income, on the aggregate. Higher crop yields probably pay off more than they cost, especially if increasing commodity prices are realized.

All the benefits of higher yields may not become visible if analysed only on crop farms. It is important to evaluate the contribution of yield development at the sector level, at least in the case of Finnish agriculture with its high production costs, livestock dominance, and some dependence on farm subsidies. The relatively most competitive regions within a country can increase production due to higher crop yields, and this may result in reduced costs 
per unit produced. The same kind of situation applies to agriculture in many other countries in Europe, also characterized by highly variable production conditions within a country, relatively high production costs compared to market prices, and a significant value of farm subsidies when compared to farm incomes.

Higher yields are likely to be profitable for farmers and may provide important societal gains, but their realization requires increasing global prices and policy schemes which allow sufficient changes in the use of inputs, necessary for successful adaptations at the farm level. Increased use of certain inputs, such as fertilizers, may not harm the environment if it leads to higher crop yields and a reduced need for intensive production area. The results suggest, however, that significantly increasing production in northern Europe is unlikely due to high production costs and budgetary constraints of current agricultural support payments.

\section{Acknowledgements}

Financial support from ADIOSO (decision number 255954) and MARISPLAN (decision number 140840), funded from the FICCA programme of the Academy of Finland (www.aka.fi/ficca), is gratefully acknowledged. This work benefitted from participation in FACCE MACSUR www.macsur.eu. The author's participation in FACCE MACSUR is funded by the Ministry of Agriculture and Forestry of Finland.

\section{References}

Berry, P.M., Rounsevell, M.D.A., Harrison, P.A. \& Audsley, E. 2006. Assessing the vulnerability of agricultural land use and species to climate change and the role of policy in facilitating adaptation. Environmental Science and Policy 9: 189-204.

FAO 2012. World Agriculture Towards 2030/2050. The 2012 Revision. ESA Working Paper No. 12-03. June 2012. Agricultural Development Economics Division Food and Agriculture Organization of the United Nations. 154 p.

Godfray H.C.J., Beddington, J.R., Crute, I.R., Haddad, L., Lawrence, D., Muir, J.F., Pretty, J., Robinson, S., Thomas, S.M. \& Toulmin, C. 2010. Food security: The challenge of feeding 9 billion people. Science 327: 812-818.

Hakala, K., Hannukkala, A., Huusela-Veistola, E., Jalli, M., \& Peltonen-Sainio, P. 2011. Pests and diseases in a changing climate a major challenge for Finnish crop production. Agricultural and Food Science 20: 3-14.

HELCOM 2013. Overview of implementation of the HELCOM Baltic Sea Action Plan (BSAP). Document prepared for the 2013 HELCOM Ministerial meeting. 40 p. http://helcom.fi/Documents/Ministerial2013/Associated\%20documents/Supporting/BSAP_Overview_with\%20cover.pdf. Accessed October 132015.

Huhtamäki, T. 2014. ProTuotos-karjojen rehustus vuonna 2013. Maidon- ja nurmentuotannon tulosseminaari 2013. http://www. proagria.fi/sites/default/files/attachment/rehunkulutus_tulosseminaari_240413_huhtamaki.pdf. Accessed August 26 2015. (In Finnish).

Höglind, M., Thorsen, S.M. \& Semenov, M, A. 2013. Assessing uncertainties in impact of climate change on grass production in Northern Europe using ensembles of global climate models. Agricultural and Forest Meteorology 170: 103-113.

IPCC 2014. Climate Change 2014: Impacts, Adaptation, and Vulnerability. Part B: Regional Aspects. Contribution of Working Group II to the Fifth Assessment Report of the Intergovernmental Panel on Climate Change. Cambridge University Press, Cambridge, United Kingdom. 688 p.

Jylhä, K., Ruosteenoja, K., Räisänen, J., Venäläinen, A., Tuomenvirta, H., Ruokolainen, L., Saku, S. \& Seitola, S. 2009. Arvioita Suomen muuttuvasta ilmastosta sopeutumis-tutkimuksia varten (The changing climate in Finland: estimates for adaptation studies). ACCLIM-hankkeen raportti 2009. Ilmatieteen laitos, Raportteja 2009: 4. 102 p. (Extended abstract and captions for figures and tables also in English).

Lehtonen, H. 2001. Principles, structure and application of dynamic regional sector model of Finnish agriculture. Academic dissertation. Systems Analysis Laboratory, Helsinki University of Technology. Publications 98. Agrifood Research Finland, Economic Research (MTTL), Helsinki. 265 p.

Lehtonen, H. 2013. Sector-level economic modeling as a tool in evaluating greenhouse gas mitigation options. Acta Agriculturae Scandinavica, Section A - Animal Science 62: 326-335.

Lehtonen, H., Liu, X. \& Purola, T. 2014a. Endogenising yield development through management and crop rotation decisions in dynamic farm level modeling. In: 24. Jahrestagung der Österreichischen Gesellschaft für Agrarökonomie, Universität für Bodenkultur Wien 25.-26. September 2014. Tagungsband 2014: 13-14.

Lehtonen, H., Liu, X. \& Purola, T. 2015. Balancing Climate Change Mitigation and Adaptation with Socio-Economic Goals at Farms in Northern Europe. In: Järvelä, M. \& Paloviita, A. (eds). Climate Change Adaptation and Food Supply Chain Management. London, UK: Routledge. p. 132-146.

Lehtonen, I., Ruosteenoja, K. \& Jylhä, K. 2014b. Projected changes in European extreme precipitation indices on the basis of global and regional climate model ensembles. International Journal of Climatology 34: 1208-1222.

Luke 2015. Economydoctor -A tool for monitoring the profitability of agricultural enterprices. https://portal.mtt.fi/portal/page/ portal/economydoctor. Accessed 13.10.2015.

Martin, W., lanchovichina, E. \& Dimaranan, B. 2008. Economic Development in emerging Asian markets: Implications for Europe. European Review of Agricultural Economics 35: 303-330. 
Nelson, G.A., Valin, H., Sand, R.D., Havlík, P., Ahammadd, H., Derynge, D., Elliott, J.,Fujimori, S., Hasegawah, T., Heyhoed, E., Kylei, P., von Lampe, M., Lotze-Campen, H., Mason d'Croza, D., van Meijl, H., van der Mensbruggh, D., Müller, C., Popp, A., Robertson, S., Schmid, E., Schmitz, C., Tabeau, A. \& Willenbockel, D. 2014. Climate change effects on agriculture: Economic responses to biophysical shocks. Proceedings of the National Academy of Sciences of the United States of America 111: 3274-3279.

Niemi, J. \& Ahlstedt, J. (eds.) 2012. Finnish Agriculture and Rural Industries 2012. Agrifood Research Finland, Economic Research Finland. Publications 112a. 100 p.

Olesen, J. \& Bindi, M. 2002. Consequences of climate change for European agricultural productivity, land use and policy. European Journal of Agronomy 16: 239-262.

Olesen J., Trnka M., Kersebaum K., Skjelvågd, A.O., Seguine, B., Peltonen-Sainio, P., Rossig, F., Kozyrah, J. \& Micalei, F. 2011. Impacts and adaptation of European crop production systems to climate change. European Journal of Agronomy 34: 96-112.

Palosuo, T., Rötter, P., Salo, T., Peltonen-Sainio, P., Tao, F. \& Lehtonen, H. 2015. Effects of climate and historical adaptation measures on barley yield trends in Finland. Climate Research 65: 221-236.

Peltonen-Sainio, P., Jauhiainen, L., Hakala, K. \& Ojanen, H. 2009. Climate change and prolongation of growing season: changes in regional potential for field crop production in Finland. Agricultural and Food Science 18: 171-190.

Peltonen-Sainio, P., Salo, T., Jauhiainen, L., Lehtonen, H. \& Sieviläinen, E. 2015. Static yields and quality issues: Is the agrienvironment program the primary driver? AMBIO 44: 544-556.

ProAgria 2010. Maatalouskalenteri 2011. ProAgria Keskusten liitto. 244 p. (In Finnish).

Purola, T. 2013. Taudinkestävien ja tautialttiiden ohralajikkeiden taloudellinen vertailu. Masters' Thesis. University of Helsinki. Department of economics and management. 98 p. (Abstract in English).

Rogelj, J., Meinshausen, M. \& Knutti, R. 2012. Global warming under old and new scenarios using IPCC climate sensitivity range estimates. Nature Climate Change 2: 248-253.

Ruosteenoja, K., Räisänen, J. \& Pirinen, P. 2010. Projected changes in thermal seasons and the growing season in Finland. International Journal of Climatology 30: 1473-1487.

Rötter R.P., Palosuo T., Pirttioja N.K., Dubrovsky, M., Salo, T., Fronzek, S., Aikasalo, R., Tnrka, M., Ristolainen, A. \& Carter, T.C. 2011. What would happen to barley production in Finland if global warming exceeded $4{ }^{\circ} \mathrm{C}$ ? A model-based assessment. European Journal of Agronomy 35: 205-214.

Rötter, R.P, Höhn, J.G. \& Fronzek, S. 2012. Projections of climate change impacts on crop production: A global and a Nordic perspective. Acta Agriculturae Scandinavica, Section A - Animal Science 62: 166-180.

Rötter, R. P., Höhn, J., Trnka, M., Fronzek, S., Carter, T. R., \& Kahiluoto H. 2013. Modelling shifts in agroclimate and crop cultivar response under climate change. Ecology and Evolution 3: 4197-4214.

Tilman, D.,Balzerb, C., Hillc, J., \& Befort, B.L. 2011. Global food demand and the sustainable intensification of agriculture. Proceedings of the National Academy of Sciences of the United States of America 108: 20260-20264. 